\title{
Sphingosine 1-Phosphate: A Novel Target for Lung Disorders
}

\author{
Sabira Mohammed ${ }^{1,2}$ and K. B. Harikumar ${ }^{1 *}$ \\ ${ }^{1}$ Cancer Research Program, Rajiv Gandhi Centre for Biotechnology, Thiruvananthapuram, India, ${ }^{2}$ Manipal Academy of \\ Higher Education, Manipal, India
}

Sphingosine 1-phosphate (S1P) is involved in a wide range of cellular processes, which include proliferation, apoptosis, lymphocyte egress, endothelial barrier function, angiogenesis, and inflammation. S1P is produced by two isoenzymes, namely, sphingosine kinase 1 and 2 (SphK1 and 2) and once produced, S1P can act both in an autocrine and paracrine manner. S1P can be dephosphorylated back to sphingosine by two phosphatases (SGPP 1 and 2) or can be irreversibly cleaved by S1P lyase. S1P has a diverse range of functions, which is mediated in a receptor dependent, through G-protein coupled receptors (S1PR1-5) or receptor independent manner, through intracellular targets such as HDACs and TRAF2. The involvement of S1P signaling has been confirmed in various disease conditions including lung diseases. The SphK inhibitors and S1PR modulators are currently under clinical trials for different pathophysiological conditions. There is a significant effort in targeting various components of S1P signaling for several diseases. This review focuses on the ways in which S1P signaling can be therapeutically targeted in lung disorders.

Hridayesh Prakash,

Edited by:

University of Hyderabad, India

Keywords: sphingosine kinase, sphingosine 1-phosphate, S1PR, lung diseases, asthma, FTY720

Reviewed by:

Kiyoshi Hirahara,

Chiba University, Japan

Elsa Anes,

Universidade de Lisboa, Portugal

${ }^{*}$ Correspondence:

K. B. Harikumar harikumar@rgcb.res.in

Specialty section:

This article was submitted

to Inflammation,

a section of the journal

Frontiers in Immunology

Received: 11 November 2016

Accepted: 01 March 2017

Published: 14 March 2017

Citation:

Mohammed $S$ and Harikumar KB (2017) Sphingosine 1-Phosphate: $A$ Novel Target for Lung Disorders.

Front. Immunol. 8:296. doi: 10.3389/fimmu.2017.00296

\section{INTRODUCTION}

Sphingolipids are ubiquitous components of the cell membrane and provide structural integrity. Ceramide, one of the simplest structural sphingolipids, is converted to sphingosine which in turn is phosphorylated by two isoenzyme specific kinases, namely, SphK1 and 2 to form sphingosine 1-phosphate (S1P) (1-3). There is a tight regulation of formation and degradation of S1P within the cells, through activation of SphKs to form S1P, dephosphorylation by phosphatases (SPPs) or degradation by S1P lyase (SPL) (Figure 1). Research over the past two decades identified S1P as a potent bioactive lipid molecule that regulates various cellular processes including cell growth, apoptosis, immune regulation, etc. (4-9).

SphK/S1P axis has been implicated in several diseases and is often considered as a potential therapeutic target. The level of expression of SphK1, and thereby S1P, has been found to correlate with the disease grade, severity, and patient survival. The involvement of sphingolipids varies from cardiovascular, cancer, inflammatory diseases to obesity.

Lung diseases are broadly classified into (a) airway diseases, where the airways, which carry oxygen and other gases, are affected; (b) lung tissue diseases, which mainly affect the architecture of lung; and (c) lung circulation/pulmonary diseases, which mainly affect the blood vessels in lungs. The involvement of S1P signaling in different types of lung diseases is currently an active area of research. We summarized the effects mediated by S1P signaling in lung diseases in the following sections. 


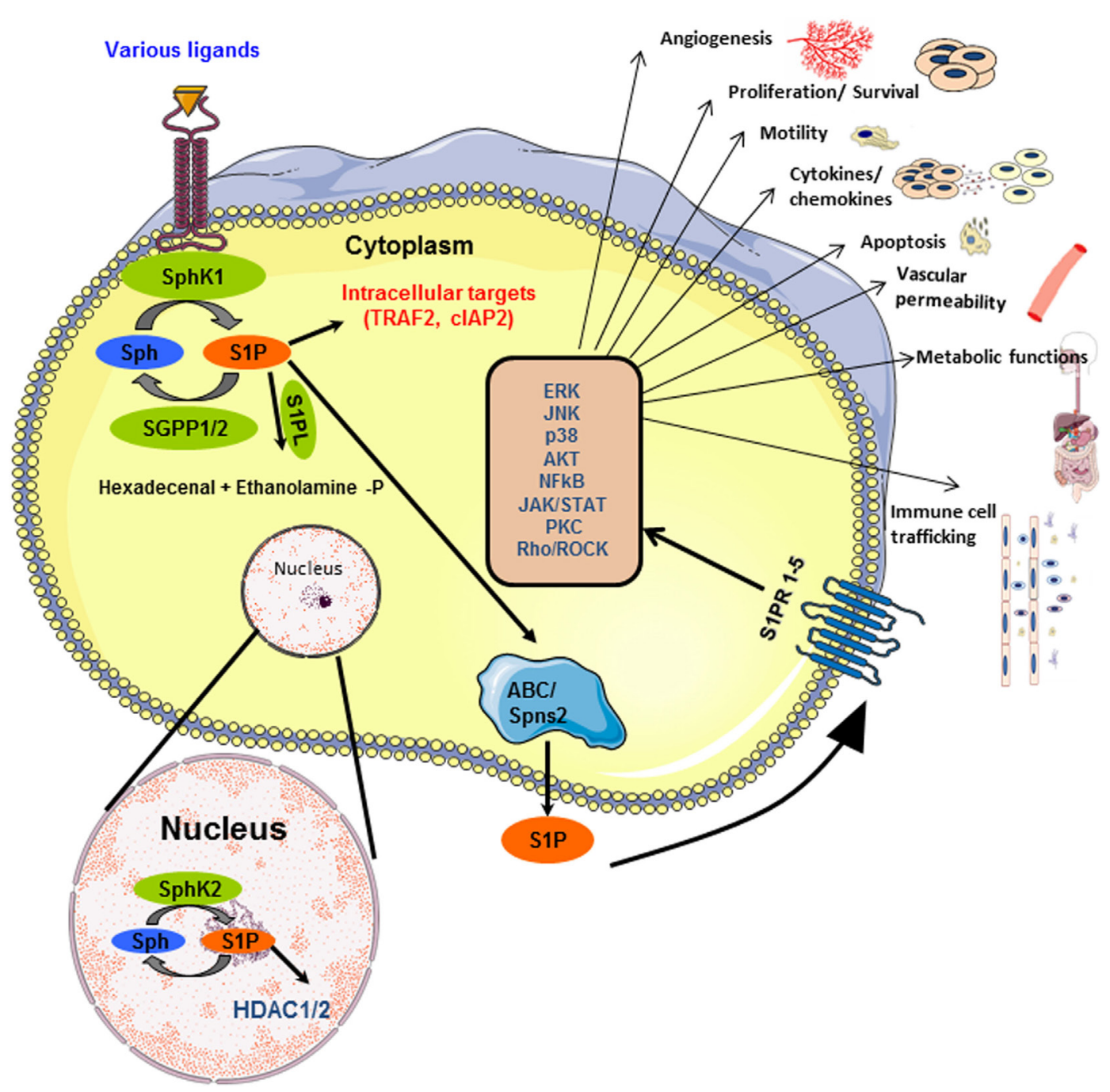

FIGURE 1 | Inside-out signaling of sphingosine 1-phosphate (S1P): SphK1 and SphK2 get activated by various ligands, in the cytoplasm and nucleus, respectively, and lead to the production of S1P. The schematic representation of the different fates of S1P is shown. S1P can be dephosphorylated to sphingosine by phosphatases (SGPP1/2) or irreversibly cleaved into hexadecenal and ethanolamine phosphate by S1P lyase. S1P, transported outside the cell by ABC transporters or Spns2, binds to any of the five G-protein-coupled receptors (S1PR1-5) on cell membrane. This activates several downstream signaling pathways. Besides this, S1P interacts with proteins such as TRAF2 in the cytoplasm and HDAC1/2 in the nucleus, thereby functioning as an intracellular second messenger.

\section{Asthma}

The recent statistics provided by Global Asthma Network indicated that the number of people diagnosed with Asthma is increasing worldwide (10). The first study about the role of S1P was reported by Choi's group using rat mast-cell line (RBL-2H3) and showed that crosslinking and stimulation of FceRI (highaffinity IgE receptor) could activate SphK1 and subsequently lead to S1P production (11). Conversely, high intracellular levels of sphingosine can block mast cell activation. Differential role of SphK1 and 2 has been observed in mast cells. Though both the isoforms are needed for production of TNF, SphK1 plays a key role in degranulation and migration towards antigen (12). S1P levels were increased in the airways of asthmatic patients but not in control subjects. Moreover, S1P also regulates the functions of airway smooth muscles during inflammation and airway remodeling (13). One of the mechanisms is through the inhibition of myosin phosphatase by S1P through a RhoA-dependent mechanism (14). Muscarinic receptor (MR) signaling that regulates airway resistance has been implicated in asthma (15). The MR downstream signaling leads to constriction of peripheral airways, and the process involves the activation of SphKs and release of intracellular $\mathrm{Ca}^{2+}$ levels (16). The systemic administration of S1P increased the airway resistance and cholinergic activity in whole mouse lung model (17). There was a marked increase on RANTES, CCR3, and IL-17 level after S1P treatment. Interestingly, S1P-mediated effects were abrogated by JTE-013 (an S1PR2 antagonist) or Y-27632 (an inhibitor of Rho kinase) indicating the role of S1PR2 $(18,19)$. This was further confirmed by silencing of S1PR2 using 
siRNA approach, which also showed the inhibition of S1P-driven Rho kinase activity. An inhibitor of SphK; SKI-II (4-[4-(4-chlorophenyl)-thiazol-2-ylamino]-phenol) was tested for its effect on bronchial smooth muscle hyperresponsiveness and airway inflammation. It was observed that the inhibitor augmented the hyperresponsiveness but had no effect on airway inflammation (20). An isoenzyme specific inhibitor of SphK1 (SK1-I) decreased airway hyperresponsiveness (AHR) and inflammation in a mast cell-dependent murine model of allergic asthma (21). SK1-I attenuated the antigen-dependent activation of both human and mouse mast cells and also reduced the circulating level of S1P in both lung and circulation. Further, NF-kB activation is a prerequisite for the pro-inflammatory cytokine production after FceRI activation. It was observed that SK1-I blocked the activation of p65 and reduced the phosphorylation of p65 at Ser276 position and was substantiated by the observation that TNF-alpha and IL-6 levels reduced after inhibitor treatment in ovalbumin challenged animals (21).

FTY720, an approved drug for multiple sclerosis, binds to all S1PRs except S1PR2 (22). Treatment with FTY720 suppressed both Th1- and Th2-driven lung inflammation. Further, this agonist inhibited the ovalbumin-induced bronchial hyper reactivity to methacholine in mice and was associated with a decrease in the lymphocyte and eosinophil count in bronchiolar alveolar lavage (23). Idzko et al. also confirmed the observation and provided more mechanistic insight for the action of FTY720 (24). The systemic administration resulted in an increase in the circulating dendritic cells along with an absence of lymphopenia and $\mathrm{T}$ cell retention in the lymph nodes. Studies were performed using isolated trachea from both mouse and rat where it was incubated with phospho-FTY720. The treatment increased the hyperresponsiveness to 5-hydroxytryptamine, and this effect was completely abolished in trachea isolated from S1PR3 ${ }^{-1-}$ mice indicating the role of S1PR3 in AHR (25). The involvement of a specific population of neurons, present in the vagal ganglia, in AHR was also analyzed. These ganglions express TRPV1 ion channel and intensify broncho constrictions very similar to that seen in asthma in sensitized lungs (26). Transcriptomic analysis of these cells revealed one of the abundant transcripts as S1PR3 (26) and further confirmatory studies indicated that S1P is one of the signals involved in the cross talk between immune cell activity and neurons in asthmatic responses.

Infiltration of B cells is another hallmark of AHR after OVA sensitization. The pretreatment of lungs with SphK inhibitors attenuates the $\mathrm{B}$ cell mobilization, thereby linking S1P signaling to B cell recruitment. S1P-dependent AHR response is associated with an immune suppressive environment as seen from increased number of Treg cells. Monoclonal antibody-based depletion of CD20+ B cells in mice was associated with S1P-dependent AHR and inflammation. The recruitment of the B cells is a mechanism to counteract the S1Pdependent inflammatory environment in lungs (27).

Of note, it was recently reported that ORM (yeast)-like protein isoform 3 (ORMDL3) gene is associated with asthma susceptibility, based on the genome-wide association studies (28). Interestingly, FTY720 reduced the ORMDL3 expression, AHR and associated inflammation, and mucus production and elevated the ceramide levels in house dust mite-induced lung inflammation model in mice, further confirming the potential beneficial role of FTY720 in the treatment of asthma (29). Moreover, mice with increased expression of ORMDL were shown to have reduced levels of different types of sphingolipids (30).

Disodium cromoglycate (DSCG), a mast cell stabilizer, is used in the therapy of asthma and is included in British Thoracic Society guidelines. It was shown that DSCG inhibited asthmalike features induced by S1P in mice as seen from the reduced recruitment of mast cells and B cells to lungs, decrease in AHR, and inflammation (31).

\section{Lung Cancer}

Lung cancer is one of the leading causes of cancer-related death worldwide. The role of SPL was investigated in the context of chemoresistance and the overexpression of this enzyme in A549 cells makes it more sensitive to cisplatin, which was mediated through upregulation of p38 and JNK pathway (32). Beneficial effects of FTY720 in reducing tumor burden in a murine model of urethane-induced lung cancer were also reported (33). S1PR3 expression was elevated in lung adenocarcinoma cell lines when compared to normal human airway epithelial cells. It was also noticed that signaling through S1PR3 increased the expression of EGFR and silencing of S1PR3 abolished the S1P-dependent EGFR activation (34). In non-small cell lung cancer (NSCLC) cells, the ectopic expression of Spns2, an S1P transporter, resulted in increased apoptosis through modulation of GSK-3 $\beta$ and Stat 3 pathways (35). A combination of ABC294640, an inhibitor of SphK2, and tumor necrosis factor-related apoptosis-inducing ligand (TRAIL) increased the apoptosis in NSCLC cell lines in vitro (36). Silencing of Sphk2 showed similar effects with TRAIL, as shown by ABC294640 (36). Studies using fibroblasts showed that S1P in nucleus, produced mainly by SphK2, interacted with hTERT. Silencing either SphK2 or S1P binding pockets leads to decreased stability of hTERT and loss of telomere integrity (37). Genetical or pharmacological inhibition of SphK2 decreased the growth of lung tumor in mice. This study demonstrated the important role of S1P in maintaining telomere stability (37). Glucosylceramide synthase, in glycolipid biosynthesis, was shown to be over expressed in lung cancer and is implicated in chemoresistance (38). Inhibition of this enzyme enhanced the anticancer potential of ABC294640 in lung cancer (39). This study advocates the possibility of a combination of SphK2 inhibitors and GCS inhibitors in lung cancer treatment.

Mesothelioma is a resistant form of cancer, which primarily develops in the lining of the lungs. Sphingosine inhibited the growth of mesothelioma cell lines and induced cell cycle arrest at the G0/G1 through the inhibition of PKC- $\delta(40)$. The elevated expression of SphK1 in malignant pleural mesothelioma tumor samples and cell lines has been reported. There is upregulation of histone acetyl transferases and a decrease in the expression of cell cycle-dependent kinase inhibitor genes (41). In a mouse model of this disease, the granulomatous inflammation (which was considered as a nearly mesothelioma like symptom) was greatly attenuated in SphK $1^{-/-}$mice as compared to SphK1 $1^{+/+}$mice (41) indicating the possibility of targeting SphK1 for the treatment of mesothelioma. However, this study does not exclude the role of SphK2 in mesothelioma, which requires further investigations. 


\section{Pulmonary Hypertension (PH)}

The role of sphingolipids in $\mathrm{PH}$ is also being identified. SphK1 and S1P were elevated in lungs of patients with $\mathrm{PH}$ as well as in animal models of hypoxia-mediated pulmonary hypertension $(\mathrm{HPH})$. There is an increased proliferation of pulmonary artery smooth muscle cells (PASMCs), and associated pulmonary vascular remodeling is observed during PAH. Elevated levels of S1P has been detected in the plasma of PAH patients (42). The SphK $1^{-/-}$mice were protected against $\mathrm{HPH}$ as seen from reduced right ventricular systolic pressure and less severe pulmonary vascular remodeling (43). Interestingly, there was no protective effect in SphK2 ${ }^{-/}$against $\mathrm{HPH}$ indicating the beneficial role of SphK 1 inhibition in the treatment of $\mathrm{PH}$ (43). S1P promoted the PASMCs proliferation $(44,45)$ through S1PR2, and this effect was nullified in SphK1 $1^{-/-}$mice. The involvement of S1PR2 was further confirmed by employing JTE-012, which prevented HPH and vascular remodeling (44). The treatment of rats suffering from the late stage of PAH with SphK1 attenuated the disease severity and reduced the levels of circulating S1P (45). The macrophages have a tendency to accumulate near lung arterioles and express high levels of leukotriene $\mathrm{B}_{4}\left(\mathrm{LTB}_{4}\right)$, which triggers cell death in pulmonary artery endothelial cells. This effect was mediated through inhibition of SphK1-eNOS signaling (44). The blocking of LTB4 production reversed fulminant $\mathrm{PH}$ through the restoration of the SphK1-eNOS pathway. Hypoxic pulmonary vasoconstriction (HPV) is also a contributing factor for PH. Recently, the role of cystic fibrosis transmembrane regulator (CFTR) is highlighted in HPV. It was observed that neutral sphingomyelinase and hypoxiainduced pulmonary vasoconstriction were inhibited by genetic or pharmacological silencing of SphK1 or through antagonism of S1PR 2 and 4 (45). These studies effectively pointed out the importance of S1P signaling in $\mathrm{PH}$ and can be the molecular target in the treatment of $\mathrm{PH}$.

\section{Cystic Fibrosis (CF)}

Cystic fibrosis is a multisystem genetic disorder, which mainly affects the lungs. The study by $\mathrm{Xu}$ et al. (46) showed that the functionally impaired lung dendritic cells contribute to the development of CF. The decreased level of S1P in the BALF results in a reduced recruitment of dendritic cells to the lungs and also affects the activation. The exogenous addition of S1P or FTY720 to the CF BALF could restore the expression of MHCII and CD40. This effect seems to be mediated through S1PR as the addition of JTE-013 and VPC20319 (an S1PR1/3 agonist) brought down the expression of the activation markers. The dysfunction of CFTR alters immune cell responses, and CFTR is involved in cellular uptake of S1P. The reduced expression of CFTR in CF will lead to a reduced uptake of S1P. Thus, S1P would be available to bring in an exacerbated cycle of inflammation and angiogenesis as seen in CF (47). S1P inhibits the CFTR activity through AMPK (48) and controls its own degradation through CFTR conductance modulation that depends on AMPK and S1PR2. The expression of a mutated form of CFTR $(\Delta$ F508) is observed in a vast majority of CF patients and leads to an increased sphingolipid synthesis, which indicated that CFTR functions as a feedback system in sphingolipid biosynthesis (49). The level of S1P was found to be reduced in a mutant form of CFTR mouse. However, treatment with SPL inhibitor (LX2931) could restore the S1P levels. Moreover, the CF phenotype of CFTR mutant mice was partially corrected by LX2931 further confirming the possible therapeutic targeting of S1P signaling in CF (50).

\section{Pulmonary Fibrosis (PF)}

Pulmonary fibrosis thickens the alveoli leading to the development of scars and is associated with severe breathing problems. SPL is reported to be an endogenous inhibitor of pulmonary fibrosis (51). The expression levels of SphK1 and SphK2 were found to be high in idiopathic pulmonary fibrosis patients, and the level of expression correlated with the severity of the disease. The knockdown of SphK1 protected mice from lung fibrogenesis. The levels of S1P and dihydro S1P were high in mice challenged with bleomycin. Administration of SK-II reduced the levels of the sphingolipids and protected against the disease and the disease associated mortality (52). A similar effect was seen in radiationinduced pulmonary fibrosis, where treatment with myriocin reduced the S1P and dihydro S1P levels, thereby reducing the onset of the disease (53). The EMT that is associated with PF has an increased level of S1P associated with it. S1P-mediated EMT through interaction with S1PR2 and S1PR3 and activates p-Smad3, RhoA-GTP, and TGF- $\beta$ (54).

\section{Acute Lung Injury (ALI) or Acute Respiratory Distress Syndrome (ARDS)}

Acute lung injury/acute respiratory distress syndrome is an acute respiratory failure associated with substantial morbidity and mortality to patients (55). Loss of Forkhead protein (FOXF1) in endothelial cells leads to ALI and administration of S1P reduced the lung edema and promoted survival (56). Further, knockdown of FOXF1 leads to increased expression of S1PR1 and thereby maintain the endothelial barrier integrity (56). Genetic screening of ALI subjects found a striking link between a single nucleotide polymorphism in cortactin gene and ALI. Cortactin is involved in maintaining barrier integrity. Interestingly, this polymorphism in cortactin was responsible for diminishing the barrier protective effects of S1P in endothelial cells making them more susceptible to ALI (57). SphK1 also afford protection against radiation-induced lung injury (RILI). SphK1 ${ }^{-/-}$mice were highly susceptible to RILI and S1P receptor agonists like FTY720, p-FTY720, and SEW2871 attenuated RILI (58).

Glucocorticoids are currently in trials for ALI. Treatment with glucocorticoids leads to the enhanced synthesis of SphK1 and S1P production. Conversely, silencing SphK1 expression attenuated the effects of glucocorticoids in ALI. SphK1 $1^{-/-}$mice were more susceptible for LPS induced vascular leakage and were associated with delayed clearance of histamine and poor recovery from anaphylaxis, and these adverse events were reversed by administering exogenous S1P (59). The role of S1PR2 has been investigated in mast cell-dependent passive systemic anaphylaxis and found that pharmacological or genetic silencing of S1PR2 reduced the antigen-induced lung perivascular edema and anaphylactic responses. Mast cells increased the T cell recruitment through S1PR2 signaling coupled to STAT3 pathway. This, in turn, leads to production of chemokines in acute pulmonary allergic responses. Studies using antibody 
TABLE 1 | Sphingosine 1-phosphate (S1P) signaling in lung disorders: the effects of different inhibitors of SphKs, S1P receptor modulators, and S1P antibody in different diseases related to lung with possible mechanism of action.

\begin{tabular}{|c|c|c|c|c|c|}
\hline S. no. & Drug used & Disease & Model & Mechanism of action & Reference \\
\hline 1 & JTE-013 & Asthma & $\begin{array}{l}\text { Human bronchial smooth muscle } \\
\text { (BSM) cells }\end{array}$ & $\begin{array}{l}\text { Suppression of S1P-induced inhibition of RANTES } \\
\text { production }\end{array}$ & $(18)$ \\
\hline 2 & JTE-013 & Asthma & $\begin{array}{l}\text { Mouse model of allergic airway } \\
\text { inflammation }\end{array}$ & Inhibition of S1P-mediated BSM contraction & (19) \\
\hline 3 & SKI-II & Asthma & $\begin{array}{l}\text { Ovalbumin-sensitized mouse } \\
\text { model }\end{array}$ & Alleviation of BSM hyperresponsiveness & (20) \\
\hline 4 & $\begin{array}{l}\text { Inhibitor of } \\
\text { SphK1 }\end{array}$ & Asthma & $\begin{array}{l}\text { Mast cell-dependent mouse model } \\
\text { of ovalbumin-induced asthma }\end{array}$ & $\begin{array}{l}\text { Inhibition of antigen-dependent mast cell activation and } \\
\text { NF-kB activation }\end{array}$ & $(21)$ \\
\hline 5 & FTY720 & Asthma & $\begin{array}{l}\text { Antigen-sensitized murine asthma } \\
\text { model }\end{array}$ & $\begin{array}{l}\text { Inhibition of Th1- and Th2-mediated airway inflammation, } \\
\text { inhibition of T cell, and eosinophil infiltration into bronchial } \\
\text { tissue }\end{array}$ & $(23)$ \\
\hline 6 & FTY720, S1P & Asthma & Mouse asthma model & $\begin{array}{l}\text { Suppression of Th2-dependent eosinophilic airway } \\
\text { inflammation and bronchial hyperresponsiveness }\end{array}$ & $(24)$ \\
\hline 7 & $\begin{array}{l}\text { SphKI/II } \\
\text { inhibitor }\end{array}$ & Asthma & OVA-sensitized BALB/c mice & $\begin{array}{l}\text { Inhibits phosphorylation of sphingosine and reduced B cell } \\
\text { infiltration into lungs }\end{array}$ & $(28)$ \\
\hline 8 & FTY 720 & Asthma & $\begin{array}{l}\text { House dust mite model of allergic } \\
\text { lung inflammation in C57BL/6J } \\
\text { mice }\end{array}$ & Attenuates ORMDL3 expression & (29) \\
\hline 9 & FTY 720 & Lung cancer & $\begin{array}{l}\text { Urethane-induced lung cancer in } \\
\text { BALB/c mice }\end{array}$ & $\begin{array}{l}\text { Decreased PCNA, increased caspase expression, and } \\
\text { impaired tumor development }\end{array}$ & (33) \\
\hline 10 & ABC294640 & Lung cancer & $\begin{array}{l}\text { Non-small cell lung cancer cell } \\
\text { lines }\end{array}$ & $\begin{array}{l}\text { Augmentation of antitumor effect of tumor necrosis factor- } \\
\text { related apoptosis-inducing ligand and upregulation of death } \\
\text { receptor expression }\end{array}$ & $(36)$ \\
\hline 11 & ABC294640 & Lung cancer & A549 xenografts in SCID mice & Reduced hTERT expression & $(37)$ \\
\hline 12 & Sphingosine & Mesothelioma & Mesothelioma cell lines & Inhibition of PKC- $\delta$ and induction of cell cycle arrest & $(40)$ \\
\hline 13 & JTE-013 & $\begin{array}{l}\text { Pulmonary } \\
\text { hypertension }(\mathrm{PH})\end{array}$ & Hypoxia-mediated PH model & $\begin{array}{l}\text { Prevention of development of hypoxia-mediated pulmonary } \\
\text { hypertension }\end{array}$ & $(42)$ \\
\hline 14 & $\mathrm{SKI} 2$ & $\mathrm{PH}$ & $\begin{array}{l}\text { Hypoxia-mediated PH model in } \\
\text { rodents }\end{array}$ & $\begin{array}{l}\text { Reduced right ventricular systolic pressure, right ventricular } \\
\text { hypertrophy, and pulmonary remodeling }\end{array}$ & $(42)$ \\
\hline 15 & SKI-II & $\mathrm{PH}$ & $\begin{array}{l}\text { Pulmonary arterial smooth muscle } \\
\text { cells }\end{array}$ & $\begin{array}{l}\text { Attenuation of hypoxia-induced increase in pulmonary arterial } \\
\text { pressure }\end{array}$ & $(45)$ \\
\hline 16 & JTE-013 & $\begin{array}{l}\text { Hypoxic pulmonary } \\
\text { vasoconstriction }\end{array}$ & Perfused murine lungs & Reduction in pulmonary arterial pressure & $(45)$ \\
\hline 17 & JTE-013 & Cystic fibrosis (CF) & Lung dendritic cells & Reduced expression of MHCII and CD40 & $(46)$ \\
\hline 18 & VPC23019 & CF & Lung dendritic cells & Reduced expression of $\mathrm{MHCll}$ and CD40 & $(46)$ \\
\hline 19 & LX2931 & CF & $\begin{array}{l}\text { Cystic fibrosis transmembrane } \\
\text { regulator mutant mice }\end{array}$ & $\begin{array}{l}\text { Increases level of S1P, normalization of the MoDC/cDC } \\
\text { ratio, reduction in T and B cells, and normalization of pro- } \\
\text { inflammatory cytokine levels }\end{array}$ & $(50)$ \\
\hline 21 & Myriocin & PF & $\begin{array}{l}\text { Mouse model of radiation-induced } \\
\text { pulmonary fibrosis }\end{array}$ & $\begin{array}{l}\text { Blocks sphingolipid de novo biosynthesis and reduced level } \\
\text { of SphK1 and serine palmitoyl transferase }\end{array}$ & $(53)$ \\
\hline 22 & S1P & $\begin{array}{l}\text { Acute lung injury } \\
\text { (ALI) }\end{array}$ & $\begin{array}{l}\text { Conditional FOXF1 knock out mice } \\
\text { model }\end{array}$ & $\begin{array}{l}\text { Restored endothelial barrier function and decreased lung } \\
\text { edema }\end{array}$ & $(56)$ \\
\hline 23 & SEW2781 & ALI & LPS induced vascular leakage & $\begin{array}{l}\text { Reduced vascular leakage and strengthening of endothelial } \\
\text { barrier }\end{array}$ & $(59)$ \\
\hline 24 & Sphingomab & Anaphylaxis & $\begin{array}{l}\text { Antigen-induced allergic response } \\
\text { murine model }\end{array}$ & $\begin{array}{l}\text { Inhibition of mast cell activation and reduction in histamines, } \\
\text { cytokines, and chemokines }\end{array}$ & $(60)$ \\
\hline 25 & JTE-013 & Anaphylaxis & $\begin{array}{l}\text { Antigen-induced allergic response } \\
\text { murine model }\end{array}$ & $\begin{array}{l}\text { Inhibition of mast cell activation and reduction in histamines, } \\
\text { cytokines, and chemokines }\end{array}$ & (60) \\
\hline 26 & $\begin{array}{l}\text { CYM-5442, } \\
\text { RP-002, }\end{array}$ & Influenza & $\begin{array}{l}\text { C57BL/6 mice infected with } \\
\text { influenza virus }\end{array}$ & $\begin{array}{l}\text { Reduction in cytokine and chemokine production, inhibition } \\
\text { of macrophage, and natural killer cell accumulation in lungs }\end{array}$ & (66) \\
\hline
\end{tabular}

AAL-R 
against S1P and S1PR2 agonists demonstrated that chemokine secretion and recruitment of $\mathrm{T}$ cells were reduced, further confirming the role of S1PR2 (60). Cui et al. reported another mechanism for S1PR2 where it inhibited the signaling through Akt, eNOS, and nitric oxide production and protected the animals from anaphylactic shock (61).

\section{Chronic Obstructive Pulmonary Disease (COPD)}

Chronic obstructive pulmonary disease is an umbrella term referring to chronic pathological conditions affecting the respiratory system (62). Cordts et al. reported the mRNA expression profiling of S1PRs in the lungs of COPD patients showed significant decrease in S1PR5 and proposed that this receptor can be a novel target for pharmacotherapy (63). mRNA expression profiles of different SphKs, S1PRs, SPL, and phosphatase were analyzed in COPD patients and found significant upregulation of SphKs, S1PR2, and S1PR5 (63). The role of S1P signaling in efferocytosis was also reported. Cigarette smoke-inhibited efferocytosis was significantly reversed by either S1P or FTY720 (64). These observations further support the notion that S1P pathway can be a potential therapeutic target in COPD.

\section{Influenza}

Influenza viruses are seasonal human pathogens causing pandemic morbidity and mortality. S1P-signaling components have been shown to interfere with virus infection and replication. SPL overexpressing cells were found to be resistant for viral amplification as compared to vector transfected cells as evident from reduced viral titer. The SPL overexpression leads to rapid activation of both STAT1 and ERK pathways (65). Teijaro et al. reported that during influenza infections, S1PR1 agonism was effective in suppressing pro-inflammatory cytokine and chemokine production as well as innate immune cell recruitment (66). S1PR1 located mainly in the pulmonary endothelial cells and agonists such as CYM-5442, RP-002, and AAL-R (67) were effective in protecting the mice from lethal

\section{REFERENCES}

1. Spiegel S, Milstien S. The outs and the ins of sphingosine-1-phosphate in immunity. Nat Rev Immunol (2011) 11(6):403-15. doi:10.1038/nri2974

2. Maceyka M, Harikumar KB, Milstien S, Spiegel S. Sphingosine-1-phosphate signaling and its role in disease. Trends Cell Biol (2012) 22(1):50-60. doi:10.1016/j.tcb.2011.09.003

3. Maceyka M, Spiegel S. Sphingolipid metabolites in inflammatory disease. Nature (2014) 510:58-67. doi:10.1038/nature13475

4. Vogt D, Stark H. Therapeutic strategies and pharmacological tools influencing S1P signaling and metabolism. Med Res Rev (2016) 37(1):3-51. doi: $10.1002 /$ med. 21402

5. Pyne S, Adams DR, Pyne NJ. Sphingosine 1-phosphate and sphingosine kinases in health and disease: recent advances. Prog Lipid Res (2016) 62:93-106. doi:10.1016/j.plipres.2016.03.001

6. Yester JW, Tizazu E, Harikumar KB, Kordula T. Extracellular and intracellular sphingosine-1-phosphate in cancer. Cancer Metastasis Rev (2011) 30:577-97. doi:10.1007/s10555-011-9305-0

7. Strub GM, Maceyka M, Hait NC, Milstien S, Spiegel S. Extracellular and intracellular actions of sphingosine-1-phosphate. Adv Exp Med Biol (2010) 688:141-55. doi:10.1007/978-1-4419-6741-1_10 infection with influenza virus. Using a Ferret model of human 2009 pandemic influenza virus infection, it was observed that the S1PR1 agonist RP-002 was effective in alleviating clinical symptoms and lung pathology independent of virus replication. Importantly, a combination of RP-002 and oseltamivir (an antiviral drug) was more effective in blunting immune response and suppressing viral replication (68). Thus, this study provided the advantages of combining antiviral drugs and S1PR1 modulators in the treatment of influenza infection. The various effects mediated by S1P system in different lung disorders are summarized in Table 1.

\section{CONCLUSION}

Sphingolipids are known to be involved in the development and progression of diseases. The level of SphK1 and S1P is elevated and often correlates with the disease severity. The abrogation of the enzyme and its product was found to lead to a reduction in the disease symptoms. The review thus summarizes the effects mediated by the SphK/S1P axis and stresses the importance of developing therapies targeting the signaling of sphingolipids, and hence the effective treatment of several pulmonary diseases.

\section{AUTHOR CONTRIBUTIONS}

All authors listed have made substantial and intellectual contribution in the preparation of the manuscript, and final version was approved for publication.

\section{FUNDING}

SM acknowledges senior research fellowship from ICMR (No. 3/1/3/JRF-2012/HRD-83). The work is supported by a fast track grant from Department of Science and Technology (No. SR/FT/LS-159/2012) and DBT-Ramalingaswami fellowship (No. BT/RLF/Re-entry/38/2011) to KBH.

8. Proia RL, Hla T. Emerging biology of sphingosine-1-phosphate: its role in pathogenesis and therapy. J Clin Invest (2015) 125(4):1379-87. doi:10.1172/ JCI76369

9. Yang $\mathrm{Y}$, Uhlig $\mathrm{S}$. The role of sphingolipids in respiratory disease. Ther $A d v$ Respir Dis (2011) 5(5):325-44. doi:10.1177/1753465811406772

10. Global Asthma Network. The Global Asthma Report 2014. (2014). Available from: http://www.globalasthmareport.org/burden/burden.php

11. Choi OH, Kim JH, Kinet JP. Calcium mobilization via sphingosine kinase in signalling by the Fc epsilon RI antigen receptor. Nature (1996) 380:634-6. doi:10.1038/380634a0

12. Oskeritzian CA, Alvarez SE, Hait NC, Price MM, Milstien S, Spiegel S. Distinct roles of sphingosine kinases 1 and 2 in human mast-cell functions. Blood (2008) 111(8):4193-200. doi:10.1182/blood-2007-09-115451

13. Ammit AJ, Hastie AT, Edsall LC, Hoffman RK, Amrani Y, Krymskaya VP, et al. Sphingosine 1-phosphate modulates human airway smooth muscle cell functions that promote inflammation and airway remodeling in asthma. FASEB J (2001) 15(7):1212-4. doi:10.1096/f.00-0742fje

14. Kume H, Takeda N, Oguma T, Ito S, Kondo M, Ito Y, et al. Sphingosine 1-phosphate causes airway hyper-reactivity by rho-mediated myosin phosphatase inactivation. J Pharmacol Exp Ther (2007) 320(2):766-73. doi:10.1124/ jpet.106.110718 
15. Moulton BC, Fryer AD. Muscarinic receptor antagonists, from folklore to pharmacology; finding drugs that actually work in asthma and COPD. $\mathrm{Br}$ J Pharmacol (2011) 163(1):44-52. doi:10.1111/j.1476-5381.2010.01190.x

16. Pfaff M, Powaga N, Akinci S, Schütz W, Banno Y, Wiegand S, et al. Activation of the SPHK/S1P signalling pathway is coupled to muscarinic receptor-dependent regulation of peripheral airways. Respir Res (2005) 6:48. doi:10.1186/1465-9921-6-48

17. Roviezzo F, D’Agostino B, Brancaleone V, De Gruttola L, Bucci M, De Dominicis G, et al. Systemic administration of sphingosine-1-phosphate increases bronchial hyperresponsiveness in the mouse. Am J Respir Cell Mol Biol (2010) 42(5):572-7. doi:10.1165/rcmb.2009-0108OC

18. Kawata T, Ishizuka T, Tomura H, Hisada T, Dobashi K, Tsukagoshi H, et al. Sphingosine 1-phosphate inhibits migration and RANTES production in human bronchial smooth muscle cells. Biochem Biophys Res Commun (2005) 331(2):640-7. doi:10.1016/j.bbrc.2005.03.223

19. Chiba Y, Suzuki K, Uechi M, Kurihara E, Goto K, Sakai H, et al. Downregulation of sphingosine-1-phosphate receptors in bronchial smooth muscle of mouse experimental asthma. Pharmacol Res (2010) 62(4):357-63. doi:10.1016/j. phrs.2010.05.005

20. Chiba Y, Takeuchi H, Sakai H, Misawa M. SKI-II, an inhibitor of sphingosine kinase, ameliorates antigen-induced bronchial smooth muscle hyperresponsiveness, but not airway inflammation, in mice. J Pharmacol Sci (2010) 114(3):304-10. doi:10.1254/jphs.10202FP

21. Price MM, Oskeritzian CA, Falanga YT, Harikumar KB, Allegood JC, Alvarez SE, et al. A specific sphingosine kinase 1 inhibitor attenuates airway hyperresponsiveness and inflammation in a mast cell-dependent murine model of allergic asthma. J Allergy Clin Immunol (2013) 131(2):501-11.e1. doi:10.1016/j.jaci.2012.07.014

22. Brinkmann V, Billich A, Baumruker T, Heining P, Schmouder R, Francis G, et al. Fingolimod (FTY720): discovery and development of an oral drug to treat multiple sclerosis. Nat Rev Drug Discov (2010) 9(11):883-97. doi:10.1038/ $\operatorname{nrd} 3248$

23. Sawicka E, Zuany-Amorim C, Manlius C, Trifilieff A, Brinkmann V, Kemeny $\mathrm{DM}$, et al. Inhibition of Th1- and Th2-mediated airway inflammation by the sphingosine 1-phosphate receptor agonist FTY720. J Immunol (2003) 171(11):6206-14. doi:10.4049/jimmunol.171.11.6206

24. Idzko M, Hammad H, van Nimwegen M, Kool M, Müller T, Soullié T, et al. Local application of FTY720 to the lung abrogates experimental asthma by altering dendritic cell function. J Clin Invest (2006) 116(11):2935-44. doi:10.1172/JCI28295

25. Trifilieff A, Fozard JR. Sphingosine-1-phosphate-induced airway hyperreactivity in rodents is mediated by the sphingosine-1-phosphate type 3 receptor. J Pharmacol Exp Ther (2012) 342(2):399-406. doi:10.1124/jpet. 112.191585

26. Tränkner D, Hahne N, Sugino K, Hoon MA, Zuker C. Population of sensory neurons essential for asthmatic hyperreactivity of inflamed airways. Proc Natl Acad Sci U S A (2014) 111(31):11515-20. doi:10.1073/pnas.1411032111

27. Sorrentino R, Bertolino A, Terlizzi M, Iacono VM, Maiolino P, Cirino G, et al. B cell depletion increases sphingosine-1-phosphate-dependent airway inflammation in mice. Am J Respir Cell Mol Biol (2015) 52(5):571-83. doi:10.1165/ rcmb.2014-0207OC

28. Shi H, Cheng D, Yi L, Huo X, Zhang K, Zhen G. Association between ORMDL3 polymorphism and susceptibility to asthma: a meta-analysis. Int J Clin Exp Med (2015) 8(3):3173-83.

29. Oyeniran C, Sturgill JL, Hait NC, Huang WC, Avni D, Maceyka M, et al. Aberrant ORM(yeast)-like protein isoform 3 (ORMDL3) expression dysregulates ceramide homeostasis in cells and ceramide exacerbates allergic asthma in mice. J Allergy Clin Immunol (2015) 136(4):1035-46.e6. doi:10.1016/j. jaci.2015.02.031

30. Miller M, Rosenthal P, Beppu A, Gordillo R, Broide DH. ORMDL3 transgenic mice have reduced levels of sphingolipids including sphingosine-1-phosphate and ceramide. JAllergy Clin Immunol (2016). doi:10.1016/j.jaci.2016. 08.053

31. Roviezzo F, Sorrentino R, Iacono VM, Brancaleone V, Terlizzi M, Riemma MA, et al. Disodium cromoglycate inhibits asthma-like features induced by sphingosine-1-phosphate. Pharmacol Res (2016) 113(Pt A):626-35. doi:10.1016/j.phrs.2016.09.014

32. Min J, Van Veldhoven PP, Zhang L, Hanigan MH, Alexander H, Alexander S. Sphingosine-1-phosphate lyase regulates sensitivity of human cells to select chemotherapy drugs in a p38-dependent manner. Mol Cancer Res (2005) 3(5):287-96. doi:10.1158/1541-7786.MCR-04-0197

33. Salinas NR, Lopes CT, Palma PV, Oshima CT, Bueno V. Lung tumor development in the presence of sphingosine 1-phosphate agonist FTY720. Pathol Oncol Res (2009) 15(4):549-54. doi:10.1007/s12253-009-9152-2

34. Hsu A, Zhang W, Lee JF, An J, Ekambaram P, Liu J, et al. Sphingosine-1phosphate receptor-3 signaling up-regulates epidermal growth factor receptor and enhances epidermal growth factor receptor-mediated carcinogenic activities in cultured lung adenocarcinoma cells. Int J Oncol (2012) 40(5):1619-26. doi:10.3892/ijo.2012.1379

35. Bradley E, Dasgupta S, Jiang X, Zhao X, Zhu G, He Q, et al. Critical role of Spns2, a sphingosine-1-phosphate transporter, in lung cancer cell survival and migration.PLoS One (2014) 9(10):e110119. doi:10.1371/journal.pone.0110119

36. Yang J, Yang C, Zhang S, Mei Z, Shi M, Sun S, et al. ABC294640, a sphingosine kinase 2 inhibitor, enhances the antitumor effects of TRAIL in non-small cell lung cancer. Cancer Biol Ther (2015) 16(8):1194-204. doi:10.1080/15384047 .2015.1056944

37. Panneer Selvam S, De Palma RM, Oaks JJ, Oleinik N, Peterson YK, Stahelin $\mathrm{RV}$, et al. Binding of the sphingolipid S1P to hTERT stabilizes telomerase at the nuclear periphery by allosterically mimicking protein phosphorylation. Sci Signal (2015) 8(381):ra58. doi:10.1126/scisignal.aaa4998

38. Bleicher RJ, Cabot MC. Glucosylceramide synthase and apoptosis. Biochim Biophys Acta (2002) 1585(2-3):172-8. doi:10.1016/S1388-1981(02)00338-4

39. Guan S, Liu YY, Yan T, Zhou J. Inhibition of ceramide glucosylation sensitizes lung cancer cells to ABC294640, a first-in-class small molecule SphK2 inhibitor. Biochem Biophys Res Commun (2016) 476(4):230-6. doi:10.1016/j. bbrc.2016.05.102

40. Okuwa H, Kanno T, Fujita Y, Gotoh A, Tabata C, Fukuoka K, et al. Sphingosine suppresses mesothelioma cell proliferation by inhibiting PKC-d and inducing cell cycle arrest at the $\mathrm{G}(0) / \mathrm{G}(1)$ phase. Cell Physiol Biochem (2012) 30(4):995-1004. doi:10.1159/000341476

41. Kalari S, Moolky N, Pendyala S, Berdyshev EV, Rolle C, Kanteti R, et al. Sphingosine kinase 1 is required for mesothelioma cell proliferation: role of histone acetylation. PLoS One (2012) 7(9):e45330. doi:10.1371/journal. pone. 0045330

42. Chen J, Tang H, Sysol JR, Moreno-Vinasco L, Shioura KM, Chen T, et al. The sphingosine kinase 1/sphingosine-1-phosphate pathway in pulmonary arterial hypertension. Am J Respir Crit Care Med (2014) 190(9):1032-43. doi:10.1164/rccm.201401-0121OC

43. Gairhe S, Joshi SR, Bastola MM, McLendon JM, Oka M, Fagan KA, et al. Sphingosine-1-phosphate is involved in the occlusive arteriopathy of pulmonary arterial hypertension. Pulm Circ (2016) 6(3):369-80. doi:10.1086/ 687766

44. Tian W, Jiang X, Tamosiuniene R, Sung YK, Qian J, Dhillon G, et al. Blocking macrophage leukotriene b4 prevents endothelial injury and reverses pulmonary hypertension. Sci Transl Med (2013) 5(200):200ra117. doi:10.1126/ scitranslmed.3006674

45. Tabeling C, Yu H, Wang L, Ranke H, Goldenberg NM, Zabini D, et al. CFTR and sphingolipids mediate hypoxic pulmonary vasoconstriction. Proc Natl Acad Sci U S A (2015) 112(13):E1614-23. doi:10.1073/pnas.1421190112

46. Xu Y, Krause A, Limberis M, Worgall TS, Worgall S. Low sphingosine-1-phosphate impairs lung dendritic cells in cystic fibrosis. Am J Respir Cell Mol Biol (2013) 48(2):250-7. doi:10.1165/rcmb.2012-0021OC

47. Boujaoude LC, Bradshaw-Wilder C, Mao C, Cohn J, Ogretmen B, Hannun YA, et al. Cystic fibrosis transmembrane regulator regulates uptake of sphingoid base phosphates and lysophosphatidic acid: modulation of cellular activity of sphingosine 1-phosphate. J Biol Chem (2001) 276(38):35258-64. doi:10.1074/ jbc.M105442200

48. Malik FA, Meissner A, Semenkov I, Molinski S, Pasyk S, Ahmadi S, et al. Sphingosine-1-phosphate is a novel regulator of cystic fibrosis transmembrane conductance regulator (CFTR) activity. PLoS One (2015) 10(6):e0130313. doi:10.1371/journal.pone.0130313

49. Hamai H, Keyserman F, Quittell LM, Worgall TS. Defective CFTR increases synthesis and mass of sphingolipids that modulate membrane composition and lipid signaling. J Lipid Res (2009) 50(6):1101-8. doi:10.1194/jlr. M800427-JLR200

50. Veltman M, Stolarczyk M, Radzioch D, Wojewodka G, De Sanctis JB, Dik WA. Correction of lung inflammation in a F508delCFTR murine cystic fibrosis model by the sphingosine-1-phosphate lyase inhibitor LX2931. 
Am J Physiol Lung Cell Mol Physiol (2016) 311(5):L1000-14. doi:10.1152/ ajplung.00298.2016

51. Huang LS, Berdyshev EV, Tran JT, Xie L, Chen J, Ebenezer DL, et al. Sphingosine-1-phosphate lyase is an endogenous suppressor of pulmonary fibrosis: role of S1P signalling and autophagy. Thorax (2015) 70(12):1138-48. doi:10.1136/thoraxjnl-2014-206684

52. Huang LS, Natarajan V. Sphingolipids in pulmonary fibrosis. Adv Biol Regul (2015) 57:55-63. doi:10.1016/j.jbior.2014.09.008

53. Gorshkova I, Zhou T, Mathew B, Jacobson JR, Takekoshi D, Bhattacharya $\mathrm{P}$, et al. Inhibition of serine palmitoyltransferase delays the onset of radiation-induced pulmonary fibrosis through the negative regulation of sphingosine kinase-1 expression. J Lipid Res (2012) 53(8):1553-68. doi:10.1194/ jlr.M026039

54. Milara J, Navarro R, Juan G, Peiró T, Serrano A, Ramón M, et al. Sphingosine1-phosphate is increased in patients with idiopathic pulmonary fibrosis and mediates epithelial to mesenchymal transition. Thorax (2012) 67(2):147-56. doi:10.1136/thoraxjnl-2011-200026

55. Ware LB, Matthay MA. The acute respiratory distress syndrome. N Engl J Med (2000) 342(18):1334-49. doi:10.1056/NEJM200005043421806

56. Cai Y, Bolte C, Le T, Goda C, Xu Y, Kalin TV, et al. FOXF1 maintains endothelial barrier function and prevents edema after lung injury. Sci Signal (2016) 9(424):ra40. doi:10.1126/scisignal.aad1899

57. Choi S, Camp SM, Dan A, Garcia JG, Dudek SM, Leckband DE. A genetic variant of cortactin linked to acute lung injury impairs lamellipodia dynamics and endothelial wound healing. Am J Physiol Lung Cell Mol Physiol (2015) 309(9):L983-94. doi:10.1152/ajplung.00062.2015

58. Natarajan V, Dudek SM, Jacobson JR, Moreno-Vinasco L, Huang LS, Abassi T, et al. Sphingosine-1-phosphate, FTY720, and sphingosine-1-phosphate receptors in the pathobiology of acute lung injury. Am J Respir Cell Mol Biol (2013) 49(1):6-17. doi:10.1165/rcmb.2012-0411TR

59. Vettorazzi S, Bode C, Dejager L, Frappart L, Shelest E, Klaßen C, et al. Glucocorticoids limit acute lung inflammation in concert with inflammatory stimuli by induction of SphK1. Nat Commun (2015) 6:7796. doi:10.1038/ ncomms8796

60. Oskeritzian CA, Hait NC, Wedman P, Chumanevich A, Kolawole EM, Price $\mathrm{MM}$, et al. The sphingosine-1-phosphate/sphingosine-1-phosphate receptor 2 axis regulates early airway $\mathrm{T}$-cell infiltration in murine mast cell-dependent acute allergic responses. J Allergy Clin Immunol (2015) 135(4):1008-18.e1. doi:10.1016/j.jaci.2014.10.044

61. Cui H, Okamoto Y, Yoshioka K, Du W, Takuwa N, Zhang W, et al Sphingosine-1-phosphate receptor 2 protects against anaphylactic shock through suppression of endothelial nitric oxide synthase in mice. J Allergy Clin Immunol (2013) 132(5):1205-14.e9. doi:10.1016/j.jaci.2013.07.026

62. Bettoncelli G, Blasi F, Brusasco V, Centanni S, Corrado A, De Benedetto F, et al. The clinical and integrated management of COPD. Sarcoidosis Vasc Diffuse Lung Dis (2014) 31(Suppl 1):3-21.

63. Cordts F, Pitson S, Tabeling C, Gibbins I, Moffat DF, Jersmann H, et al. Expression profile of the sphingosine kinase signalling system in the lung of patients with chronic obstructive pulmonary disease. Life Sci (2011) 89(21-22):806-11. doi:10.1016/j.lfs.2011.08.018

64. Barnawi J, Tran HB, Roscioli E, Hodge G, Jersmann H, Haberberger R, et al. Pro-phagocytic effects of thymoquinone on cigarette smoke-exposed macrophages occur by modulation of the sphingosine-1-phosphate signalling system. COPD (2016) 13(5):653-61. doi:10.3109/15412555.2016. 1153614

65. Seo YJ, Blake C, Alexander S, Hahm B. Sphingosine 1-phosphate-metabolizing enzymes control influenza virus propagation and viral cytopathogenicity. J Virol (2010) 84(16):8124-31. doi:10.1128/JVI.00510-10

66. Teijaro JR, Walsh KB, Cahalan S, Fremgen DM, Roberts E, Scott F, et al. Endothelial cells are central orchestrators of cytokine amplification during influenza virus infection. Cell (2011) 146(6):980-91. doi:10.1016/j. cell.2011.08.015

67. Matheu MP, Teijaro JR, Walsh KB, Greenberg ML, Marsolais D, Parker I, et al. Three phases of CD8 T cell response in the lung following H1N1 influenza infection and sphingosine 1 phosphate agonist therapy. PLoS One (2013) 8(3):e58033. doi:10.1371/journal.pone.0058033

68. Walsh KB, Teijaro JR, Brock LG, Fremgen DM, Collins PL, Rosen H, et al. Animal model of respiratory syncytial virus: $\mathrm{CD} 8+\mathrm{T}$ cells cause a cytokine storm that is chemically tractable by sphingosine-1-phosphate 1 receptor agonist therapy. J Virol (2014) 88(11):6281-93. doi:10.1128/JVI. 00464-14

Conflict of Interest Statement: The authors declare that the research was conducted in the absence of any commercial or financial relationships that could be construed as a potential conflict of interest.

Copyright $\odot 2017$ Mohammed and Harikumar. This is an open-access article distributed under the terms of the Creative Commons Attribution License (CC BY). The use, distribution or reproduction in other forums is permitted, provided the original author(s) or licensor are credited and that the original publication in this journal is cited, in accordance with accepted academic practice. No use, distribution or reproduction is permitted which does not comply with these terms. 